\title{
Women Under Kuomintang Rule Variations on the Feminine Mystique
}

\author{
NORMA DIAMOND \\ University of Michigan
}

One objective of this article is to present descriptive material on the life-style of the new urban middle class in Taiwan, particularly as it relates to women. This class, though still relatively small, has been growing steadily over the past decade. Taiwan is rapidly urbanizing, and the major cities have doubled or even tripled in size in a fairly short time. The goal of the government on Taiwan is to reach a level of $70 \%$ urbanization of the population by 1980 . The present new middle class is a model for the predicted city life-style of an increasingly large segment of the total Taiwan population, assuming that Taiwan is able to continue on her present course of development.

By "new middle class" I refer to that segment of the work force engaged in the modern sector of the economy. Their household income, usually based on salary, derives from employment in the professions, in governmental and private corporations and bureaucracies at the administrative and mana-

AUTHOR'S NOTE: This paper was presented in an earlier version at the conference on "Women in Chinese Society," held in San Francisco in June 1973 under the sponsorship of the Joint Committee on Contemporary China of the American Council of Learned Societies and the Social Science Research Council. For their suggestions and criticisms I would like to thank all the participants in that conference, and particular thanks to Irene Eber, Shao Ziping, Sophie Sa Winckler, and Morilyn Young.

MODERN CHINA, VoI. 1 No. 1, January 1975

(C) 1975 Sage Publications, Inc. 
gerial level, and white-collar jobs. Their income ranges between $\$ 100$ and $\$ 300$ a month in U S dollars. Those engaged in the traditional sector of the economy (landlords, small familyowned shops) are excluded here, regardless of income similarities. Also excluded from our consideration are those in the top echelons of the modern industrial economy and the national government.

My second objective is to examine family-related values and women's roles in something beyond redundant cultural terms. While the legacy of traditional Chinese culture plays some part as "explanation" of the data, there is much to be gained by additional lines of inquiry. I intend to look at Taiwan's political atmosphere and economic setting A working assumption of this line of inquiry is that economic and political developments impinge on and reshape culture and ideology. They affect family organization and size and household relationships. They affect the content of socialization, in the wider sense of the learning of values and behavioral guides through formal education, the mass media, and in the realities of post-childhood experiences. If we choose to ignore the developing political and economic scene, we are reduced to explaining ongoing behaviors and values either as continuities from the traditional past, real or spurious, or as changes lumped under the catchalls of "acculturation" and "modernization." Both these terms are useful and even relevant to some extent for this essay, but they are not wholly satisfactory. We cannot deny that some of the content of present-day Taiwan life reflects the influence of Japanese and American/European thought and practices. But selective borrowing from other societies can only be understood in the total context of the receiving-culture's experiences and organization. And "modernization" is an even less useful term. It is culture bound to a high degree, and if carelessly used, it can lead us to mistake form for content. These points will be made clearer as we get into discussion of the data.

Lastly, it is hoped that this paper succeeds in one further purpose, which is to inject a feminist consciousness into the analysis of the position of women in modern Taiwan. By 
"feminist" I mean a heightened awareness of problems shared by women across cultural boundaries and class lines, at different stages of economic development and under differing political systems. The intensity of sexual polarization varies from one society to the next, as does the content of the control over women by men and the content of oppression. To note that the intensity and content vary does not dissolve the reality of oppression of women as a special class or caste, marked by gender for peculiarly similar treatment within a wide range of societal contexts. The sexual division of labor is the oldest and most persistent such division in human society as a whole. It becomes oppressive at that point in social development when women's share in the total social endeavor is denigrated and given lesser rewards and when gender is taken as the decisive indicator of talent, ability, and expectable personality traits. The history of women in China seems to have been one of increasing oppression from the T'ang dynasty on. Changes in the past half-century have been changes in content, a modification and partial amelioration of a heavier oppression, not the ushering in of full equality. Both the government of the People's Republic of China and the Kuomintang government in Taiwan officially claim that men and women are equal in their societies: the statements of the PRC come much closer to the truth In Taiwan, such claims have far less basis. It is still valid to speak of the oppression of women as women across class lines in present-day Taiwan, and I would even suggest that this oppression has become stronger in the past decade or so despite dramatic gains made by some women earlier in the century.

\section{IDEOLOGY, POLITICS, AND WOMEN}

No occupation is denied to them and they dominate some (barbering, for example) which are usually reserved for men. The mothers of China are the strong supporters of Children's Day and the backers of legislation providing for child care and expanded education ... the women make up the core of the congregations of all the religions in Asia. 


\section{[6] MODERN CHINA / JANUARY 1975}

Girls have led the way into the industrial future with their manual dexterity and their quickness... of those in electronics and the plants of other industries requiring precision work, 90 per cent are female.

Entertainment is biz business for the Chinese young lady. Female movie stars make much more than the men. All the top singers are girls. Modeling is in its infancy, but growing fast [Free China Review, 1971].

The present-day social attitudes in Taiwan are a reflection of an ongoing political and economic milieu. It is therefore essential to examine the political-ideological posture of the KMT vis-à-vis the woman question in the years before 1949 and during their tenure in Taiwan. Although some of the older leadership had participated in the May Fourth Movement or had been influenced by it during the 1920s, the KMT's center and right wings soon moved toward a cautious conservatism and even a reactionary stance in their discussion of women's place in the family and society.

From 1927 on, radical women, including feminist women, were under attack not only from conservative elements in Chinese society generally but also directly from the Kuomintang. In her autobiographical statement (Snow, 1967: 241-242), Cai Chang recalls.

More than 1000 women leaders were killed in that year alone in all of China-not all were Communists, some were bourgeois and there were many students, but all were revolutionary leaders ... General Ho Ch'ien [sic] in my home province Hunan was the cruellest of all. He tied men to horses and split their limbs. And when girls were arrested in Hunan, they were stripped naked, nailed on crosses and their noses and breasts cut off before they were killed. This was done officially by gendarmes under command of their of ficers. After girl students were beheaded, their heads were put into men's coffins, and the gendarmes said: "You have your free love now!" If girls and men happened to be killed at the same time their heads were exchanged on their bodies. The girls' bodies were always horribly mutilated. In Hunan and Canton, Communists were not shot but beheaded with swords-girls the same. During the execution, the parents were often forced to stand witness and not permitted to cry. 
After the Canton Commune at least two hundred to three hundred girls were killed. It is actually true that if a girl had bobbed hair she was subject to execution as a Communist in Hunan and Canton.

In an interview in the early 1930s with Agnes Smedley, a woman leader identified as Chang Siao-hung gives the following description (Smedley, 1933: 85) of the take-over in Shanghai by the Kuomintang and the tragic aftermath.

Every girl with bobbed hair who was caught was stripped naked, raped by as many men as were present, then her body slit in two, from below upwards. Often the girls were no more than fifteen or sixteen, and officers, giving interviews to eager British journalists from Hong Kong, said: "The bobbed haired girls are the worst; they are very arrogant and talk back defiantly. We have had to kill hundreds of them."

Similar stories are indicated by Hsieh Ping-ying (1940) in the truncated version of her autobiography Girl Rebel as she describes the terrified flight and hiding of the women soldiers who had assisted in the Northern Expeditions and identified the Kuomintang's cause as their own. In the $1925-1927$ period it is estimated that a million and a half women had been organized in ten provinces under He Xiang-ning, chier of the Kuomintang Women's Department, and a member of the Hankow government and left wing of the KMT. (One might note that in 1925, the right wing of the KMT attempted to have her assassinated at the same time they killed her husband, Liao Zhong-kai, a close associate of Sun Yat-sen.) Working from their Hankow base, the left wing of the KMT trained women organizers, set up women's unions, provided marriage and divorce bureaus, and educated local women in the meaning of the revolution. Several hundred women were trained to work as propagandists with the army. But after Chiang's coup, these women were in direct danger. Only a handful of the top leaders were able to escape the purges that followed, and many women met their death on the evidence of bobbed hair, unbound feet, or their local reputation for having opposed familial authority in a marriage arrangement or demanded a divorce (Snow, 1967: 136-137). 
In early 1934, Chiang Kai-shek launched the New Life Movement from his Nanchang headquarters, where he served as commander-in-chief of the military operations for the suppression of communism. With the endorsement of the national government, the movement spread and became a part of the official ideology. As outlined by Chiang, the aim of the movement was a "social regeneration of China" through a revival of the moral principles of $l i, y i$, lien, and chi (propriety, justice, honesty, and self-respect), a neo-Confucian revival which would return to the traditional moral teachings and apply them to ordinary matters (Chiang, 1935). It was at this time that Chiang looked to Germany, rather than the Soviet Union, as a model. He admired the strength he saw there, which he attributed to a moral code similar to that urged by Confucian thought (Chiang, 1935: 41). The new order of fascism, with its emphasis on military power and total control, struck a chord of response within the KMT. So too did its emphasis on the patriarchal family and male supremacy. The KMT thus encouraged a backlash action against the anti-Confucianism and feminism that had crystallized in the May Fourth Movement and had held sway in the 1920s.

Lloyd Eastman, in his article on the Blue Shirts (1972) has clearly documented the fact that the inspiration for that organization and its ideology (later to be transmuted into the New Life Movement) stemmed directly from European fascist movements. Liberalism in any form was equated with license and personal indulgence. What was needed in China, or so the right wing of the KMT and Chiang himself felt, was discipline, obedience to the leader, a new asceticism, and a return to the root values of Chinese culture. Nationalism, exaltation of the state, glorification of the leader, subordination to the collective will, and the glorification of violence and terror all had their place in this school of thought. A militarized education for the young was a necessary step in spreading this orientation, and at the middle school there was formal military training for boys and nurse's training for girls. Puritanism also held sway, including sanctioned physical attacks on people attending the 
cinema or dance halls or engaging in other forms of "decadent Westernization" Even with the disbanding of the Blue Shirts in 1938, their spirit lived on in the Youth Corps (still functioning today in Taiwan in modified form).

The final death knell to an independent women's movement in the KMT-run area of the mainland came in May 1938, with a conference called at Kuling by Madame Chiang Kai-shek. Its ostensible purpose was to mobilize women for the war effort, and the fifty invited delegates included women leaders from all over the country. Some were provincial delegates, others were writers, organization heads, student leaders, and outstanding professional women. Soong Ching-ling was noticeably absent. As envisioned by the Madame, women were to play a supportive but vital role in the coming struggle with Japan. As she outlined it at the meeting, their activities would include such tasks as caring for war orphans, writing letters for the troops, providing medical care, and staffing relief agencies. What other responsibilities a women's movement might have were left unsaid. The meetings elected a standing committee, with the Madame as chairman and eminent persons such as Madame $\mathrm{H}$. H. Kung and Madame Feng Yu-xiang as members. It was also "decided" at this meeting that the Chinese Women's Advisory Committee of the New Life Movement (of which Madame Chiang was also apparently the president) would from henceforth be the agency through which all women's activities were to function (see Wei, 1943 213-219; Hahn, 1941 280-281)

During the late 1930s, Madame Chiang expounded on the position of women in a number of speeches and essays. In an article written in 1936 on the New Life Movement she expressed the idea that the education and health of a nation's women were a measure of "civilization" and that educated, able women should engage in public service "consistent with those duties that embrace the care of their homes." She made clear that her definition of public service involved teaching literacy and home management to less fortunate women and that the scope of change was to be limited 
The women must realize that mostly their thoughts and actions are not right, and they must emancipate themselves from ignorance and inertia. Their family life should be orderly, their houses clean, and they should resolutely work against gambling, smoking, drinking, extravagance and other bad habits of life [Soong, 1938. 315-321]

In an undated article from the same period, Madame Chiang enthusiastically described the curriculum for girl students in a special school for the children of revolutionary martyrs. Pointing out that "boys and girls need separate training with a view to the development of their respective talents," she describes the girls' programs from fifth grade on:

They are instructed in sewing, hosiery, embroidery, weaving, making artificial flowers, toys and rattan work. In addition to meeting their own needs, a considerable part of the hand work can be sold, as was the case at Christmas 1933 [Soong, 1938].

In fairness, one should note that the boys' studies embraced agriculture, carpentry, and building, but by Madame Chiang's own account it was only boys from these schools who were sent on to college or technical training (Soong, 1938: 323-332). Her statements about women's education changed only slightly in regard to the audience. In a 1937 message to the National Christian Council (Soong, 1938: 341-349) the Madame praised Christian mission schools for raising the status of women and sending forth educated women to improve the living conditions and status of their women compatriots. Still, she reserved particular praise here for the Women's Prayer League of Canton, an organization of 1,000 members which prayed daily for China and its leaders, pointing to it as "one of the most practical forms of patriotism." And what are we to make of her assertion in this speech that "mission schools in China had to offer girls free tuition and spending money to induce them to accept a modern education. It is to the lasting credit of the missionaries that they used every means to get girls to study" (Soong, 1938: 345). Given the social background of the times, surely it was the girl's father who had to be induced by whatever means to give permission. 
It was into hands of this kind that leadership of the women's movements fell in the late 1930s. Wartime expediency, the united front against Japan, and the strict political controls within the KMT-ruled areas did not allow for the strong expression of alternate viewpoints and positions on the women question. In an interview given to Reuters in Nanking in September 1937, Madame Chiang had already outlined her position on the activities of women in the wartime struggle (Soong, 1938: 117). It would be a rear-lines operation in which women would assist the Red Cross, provide comfort for the troops, raise funds, and arrange patriotic meetings. In addition,

The women have to assist in upholding the morale of the nation in its gravest trial; in obeying implicitly the orders of the Government, and having these orders carried out by all citizens; in suppressing rumors, and, by economies, conserving the nation's foodstuffs and apparel.

Despite her open doubts that the "physical strength and endurance of women could equal that of men," she did concede that it might be necessary for women to do farm work and even take over "many of the ordinary occupations of men" during the war. But these latter remarks were addressed to a foreign audience, and not to the people of China or the women's groups-at least, the suggestion that women join the productive labor force is not to be found in the essays and speeches prepared for internal consumption. There is also some doubt that women were widely organized even for these rear-line activities in the KMT areas.

Representative of the thought of the war-years period is a book on marriage and the family commissioned in 1943 by the Funü Yundong Weiyuanhui in Chungking ( $\mathrm{Li}, 1970$ ). Little is said about careers continuing after marriage or women's participation in the work force. Rather, women are encouraged to recognize that care of the household and children is their primary duty, and many of the chapters deal with the details of housework management. Readers are assured that no nursery school or child-care center can substitute for a mother's love 
and guidance. Conjugal love receives a great deal of emphasis, though Li tells her audience they should not begin talking about love until they are in college and should not consider marriage until after college graduation. Obviously, she is writing for a select and privileged audience, and it is significan that she stresses the domestic role even for this educated group. For those who might complain that she is defending a very traditional view of women's roles, she explains that while in the past women could only look forward to marriage, now they can go to school before marriage, and while in the past they could only do housework, now they can take an interest in national affairs, or continue to further their knowledge and intellectual development.

The more equalitarian position taken in the communist base areas during this period was anathema to the Kuomintang. As Han Suyin relates (1968: 147), even the staunch right wing of the Kuomintang found much to admire in reports coming out of the border areas, but

one accusation could be flung at them safely and that was, of course, sex. Their greatest crime was "free love," and therefore "dangerous thoughts"! They preached "equality of women"! Appalling crimes which threatened the salvation of China! Though even the most rabid anti-Red newspapers could not accuse the communists of corruption, of letting their troops die of starvation (as happened on the Chiang side), of trafficking with the enemy, they could be accused of practising orgies! They actually had women in the Red armies, girls dressed as boys and carrying guns! They encouraged slave girls and concubines to revolt against their masters! Their widows remarried! They did not insist on "chastity"! They incited the peasant women to stand up and denounce their husbands' misdeeds!

The accusations of sexual immorality and "unnatural behavior" have continued to be part of the KMT line in its propaganda war against the People's Republic. A book on the history of women in China (Yang, 1964) devotes the final chapter to a series of sick fantasies about how women are abused and sexually exploited under socialism. Participation of women in the labor 
force is referred to as "slavery," and the principle of equal pay for equal work is interpreted to mean that women must do the same heavy labor or more than men. The presence of women in the People's Liberation Army is taken as proof that they serve as military prostitutes. And the Taiwan audience is told that not only has family life been destroyed in China but that women are forced into marriage or liaisons with local or Russian "big nose" cadres, that in some cases women are forced to live with three or more men simultaneously, that they have many miscarriages because of being forced to work, and so on and so forth (Yang, 1964 337-346). Clearly the message is to count one's blessings and beware of equalitarian promises.

Kate Millett's discussion (1970. 157-168) of the position of women in Nazi Germany is pertinent here. The German fascist state bears certain similarities to the Kuomintang's system of organization and rule, both in the particulars of attitudes toward women and in the wider sense. Both were strongly militaristic and strongly anti-communist regimes, infused with a neopuritanism and distrust of human impulses unhampered by the strictest control. The uniforms, the cropped hair, the "wholesome" military discipline that continues to infuse the school system and the Youth Corps in Taiwan are in much the same spirit as the Hitler Jugend. Unquestioning allegiance to the state, to the leader, and to nationalistic goals ("fight back to the mainland") are additional points of similarity developed on the mainland and transported to Taiwan. In this ideological environment, the thinking about women shows a number of parallels.

The ideal role for women, in both Nazi Germany and KMT-ruled areas of China from 1927 on, is motherhood, which is glorified and praised publicly Mother's Day in Taiwan is an official holiday, singling out women whose children have achieved success because of maternal care and self-sacrifice. Indeed, child-rearing is held out as the most important role that a woman can play $F$ w in government circles would object to the idea that the aim of feminine education is invariably to be the future mother, and as in Germany, female admissions to 
senior middle school are limited to one-third of the total with strong emphasis on training for future wifehood and motherhood.

The exclusion of women from upper levels of the work force and the firing of married women typify both regimes, as does praise for women who remain in the more "feminine" lines of endeavor such as nursing, social work, and elementary-school teaching. Since one-sixth of the male work force is in the army at any one time in Taiwan, there must be some female participation in the upper levels of the work force and heavy participation of young unmarried women in the factories and on the farms.

As many writers have pointed out, authoritarian governments tend to favor patriarchy or some form of machismo and supermasculinity. They deny the existence of female sexuality by inhibiting and repressing it, and they relegate women to menial labor and child care tasks, turning women into a special category. The militaristic, repressive quality of state rule in Taiwan makes the home the hoped-for refuge and haven for men from the pressures of society where the man is served by others and where he takes full command. For this to occur, women must be less independent economically, less educated, and more docile and aware of their many limitations. They are simultaneously worshiped as mothers and perceived as inferior persons. The politics of the state, which conducts its internal affairs as if it were still actively at war, makes it impossible for women to organize and raise feminist demands for change in their status and in their roles, just as it makes it impossible for any dissident group to be heard: Those who question social events are not merely critics, they are potential traitors. A recent listing of 214 political prisoners being held in Taiwan cites the crimes of six as discontentment with the status quo, a transgression which carries anywhere from four to twelve years in jail. Another thirteen had "criticized the KMT" or expressed "discontent," actions which make one liable to four to fourteen years in jail (Ronin, 1972).

The official line on women in Taiwan is that their status is steadily improving. Several women's organizations are paternal- 
istically approved and encouraged by the government, which accepts their existence as a given.

The Chinese Women's Anti-Aggression League, founded by Madame Chiang, claims an active membership of 248,213 and the ability to mobilize one million women on short notice. Many, if not all, of these are drawn from military and government circles. The league's professed goal is "to mobilize women for social service and auxiliary duties in the antiCommunist struggle," though it appears to draw mainly on upper-strata women as activists. Projects and programs include voluntary sewing of clothing for military personnel, collection and donation of cash, clothes, and foodstuffs for needy military dependents, the operation of 35 milk-bars for needy children, the maintenance of schools and orphanages for war orphans and the children of civil servants and military personnel, assistance to retired servicemen, collections of clothing for Vietnamese refugees, aid for KMT soldiers returned from Burma and Vietnam (!), and relief services to needy women and overseas Chinese girl students in Taiwan. These same wartime activities have been assigned women since 1938. The members also make radio broadcasts to the mainland and sponsor free movies for military personnel and their dependents. Some 8,000 women presumably drawn from the lower strata of society are involved in classes, under the league's auspices, to learn marketable skills such as knitting, sewing, first aid, embroidery, cooking, typing, accounting, and English, as well as sculpture and flower arranging. Reportedly, over 600,000 women receive its publication, Chinese Women's Monthly (China Yearbook, 1969-1970: 338-339).

The Kuomintang Women's Department, for party members and thus an elite group, holds as its goal the safeguarding of women's rights and interests and helping women to become good housewives and citizens. It provides some legal services and maternity clinics, home-nurse visits, a monthly magazine called Women's Companion with a circulation of 8,000 , it encourages women to engage in "social and wartime services," presumably on a voluntary basis, conducts surveys on the 
condition of women, and operates classes in sewing and typing on Kinmen. In 1968-1969 it instructed 11,000 women in "environmental sanitation," a recurrent obsession in KMT circles, particularly in connection with women's work (China Yearbook 1969-1970: 339-340).

No membership figures are available for the Women's Association for the Study of Asian Problems, an umbrella organization designed to encourage an understanding of Chinese culture. It sponsors lectures and various activities for members of the foreign community. It too appears to be an elite group, similar to the Taipei International Women's Club, with its 500 members (many of whom are from the diplomatic and American military community) who engage in voluntary welfare activities and presentation of cultural events. Madame Chiang is again president of this organization (China Yearbook, 1969-1970: 340-341).

With more mass appeal than other women's groups on the list of approved organizations is the Taiwan Provincial Women's Association, numbering 96,000 members. It publishes a monthly, Taiwan Women (Taiwan funü). Its purpose is to "protect women's rights and promote women's social status, welfare, education, and marital harmony." In 1968-1969, it secured employment for some 400 women, provided legal counsel for 323 cases of family disputes, trained almost 500 women in sewing, handicrafts, and flower arranging, held symposia, and selected 345 "model families." It also provided some financial aid to almost 1,000 needy women (China Yearbook, 1969-1970. 350-351).

The magazine of the Provincial Women's Association bypasses feminist goals. For example, the March issue of 1968, presented for International Women's Day a lead article heavily reminiscent of the New Life Movement. Women were urged to turn their attention to (1) basic hygiene and sanitation (that is, collecting and disposing of garbage), (2) being thrifty, simple, and sanitary in preparing food, and, for example, not allowing bodily wastes to come into contact with food; (3) showing good manners in public places such as buses, theaters, and parks by 
not talking loudly or laughing or throwing orange peels around, by keeping off the grass, and by giving one's seat to elderly people; (4) keeping public outhouses and restrooms clean, and showing concern for the sanitary conditions and maintenance around public wells and gravesites. The fifth point dealt with upkeep and repair of homes and community buildings, including sweeping one's own yard and cleaning open sewers. Lastly, the readers were urged to bring these principles of social education to the attention of their local government organizations, police, and party officials and see that they were put into practice All this, it was promised, would make for a modernized citizenry and a country that was not only prosperous and strong, but also happy.

It is hard to judge how such exhortations go over with the readership. Since the magazine is sufficiently difficult in style to be of little appeal to those with less than a junior middle-school education, it seems unlikely that its average reader requires lecturing in the basics of hygiene and public behavior. The magazine's attraction may stem from its other articles, which are similar to those in commercial women's magazines. These include articles on infant care and child-rearing, dress patterns and recipes, beauty and grooming tips, home medical advice, and articles on the secrets of marital happiness and successful family life There are also short pieces submitted by the readership.

The readers' contributions, in the form of letters or short articles, are often very poignant in their distress. A short item in the May 1968 issue entitled "If I Were a Male" lists the various advantages that men have in current society, such as a chance to use their knowledge and abilities, the right to maintain friendships and spend their free time with friends, the right to travel around the country, the right to laugh openly, to walk with confident step, to ignore fashion and cosmetics, and (as an afterthought) to be taken seriously by their teachers in school. Yet the conclusion to the article is not a demand or even a request that women share in these privileges, but rather resignation to the idea that nowhere in the world do women 
have such privileges and by the author that if there is indeed a next life she be reborn as a boy.

This article exemplifies the limits that are put on discontent and questioning of sex-assigned roles in official publications. To take the discussion one step further and protest as a feminist does not seem to be possible in present-day Taiwan society. It is permissible to be envious of men, to resent being a woman. Indeed, it is expected that many women will be, hence the large number of articles reassuring women of the central role they play in the modern family, their crucial importance to household members, and the irreplaceable value of the tasks they perform in the mother and housewife roles. (Typical titles of articles: "A Woman's Best Friend Is Her Husband"-September 1968; "Developing Your Child's Sense of Responsibility"-November 1968; "Don't Let Your Children Become Spoiled"-December 1968; "Children Who Have Lost Maternal Love"-May 1968; "My Mother's White Hair"-May 1968.) Successful socialization of women to their adult role involves their putting aside their resentments of its confinement to the home or at least a patient resignation to the indisputable fact that one has been born female. Anatomy is destiny.

\section{THE LIFE-STYLE OF MIDDLE-CLASS WOMEN}

Between 1969 and 1971, I was engaged in a study of 240 middle-class households in Taiwan City. (Some of this material appears elsewhere; see Diamond, 1973a, 1973b.) The sample was designed to match two life-styles, not to reflect the actual distribution in the population. Of the married women in the final sample, 108 were full-time housewives, 112 were employed full time, and 20 were employed on a part-time basis, some by their husbands and others on salary. All but one had at least one child-and the childless one was pregnant. Except when I generalize about the entire sample, those working part-time will not be included in the discussion.

Because a disproportionate number of middle-class jobs are held by mainlander men, only 121 of these families are headed 
by Taiwanese husbands. The sample was selected on the basis of education and occupation, not ethnicity. One hundred fortythree of the women themselves were ethnic Taiwanese. Thirtyfour of the husbands worked for the military and/or police at the officer level. these were, of course, predominantly mainlanders. Ninety-seven can be classified as professionals (engineers, teachers and professors, scientists, court officials and judges, and so on), 65 as white-collar workers (including functionaries in the civil-service bureaucracy as well as accountants and others in private enterprise); 27 were in managerial positions, and 10 fell into a class of skilled worker/other. In terms of education, 105 of the men were college graduates, 9 had postgraduate degrees, 58 had gone to upper-level technical schools and junior colleges, 54 were senior middle-school graduates and 12 had only a junior middle-school education.

Let us now turn our attention more specifically to the women. Most had work experience, if only before marriage, in relatively good positions: 100 were in professions (mainly teachers), 102 were white-collar workers, and only 23 had never been employed. Of those still working, $45.5 \%$ were professionals and $49 \%$ were white-collar workers, with the rest scattered through police work and other jobs. Among the housewives, a high percentage had also held parallel professional and white-collar jobs (37\% of the housewives, for each of those categories), though some $20 \%$ had never worked at all. The move into full-time domesticity, therefore, had not been a flight from undesirable jobs. If one cancels out those who had never worked, the job distribution prior to marriage is similar for housewives and employed wives.

Educationally, the women as a group fall behind their spouses, which is expectable, since women even today make up only one-third of the enrollment in senior middle schools and colleges. In the entire sample, only 44 had attended college, 16 had gone to junior colleges and technical schools, 2 had done postgraduate work, 124 had gone through senior high school. Fifty-three had a junior middle-school education or less, which 
in the younger age-sets now disqualifies most of them from jobs in accord with middle-class status. Their experience before marriage had been in working-class jobs or none at all, and for them in particular the role of housewife, with no outside work, represents a step up. As one would expect, proportionately fewer housewives had college or technical schooling, and a larger percentage had less than senior middle school. It is perhaps the educational gap between spouses that makes more of the housewives regard the husband and his family as coming from a higher social position than their own household members. The reality of this is hard to check out, since many of the women, particularly those married to mainlander males, were unclear about the educational level or occupations of their husband's fathers or other kin. The social backgrounds of the two groups of women themselves are very close, except in the housewives' sample a slightly higher percentage of fathers were in the military or in business, while the employed wives were more likely to report fathers in white-collar jobs. But otherwise the percentages are equal for those with fathers in the professions, or, at the other end of the scale, those who originally came from working-class or peasant backgrounds. (In neither group were the women's mothers actively employed outside-the percentages are small, and the difference not significant except that more employed wives identified their mothers as active in farming compared with the housewives, while more of the housewives came from business families where their mothers worked in the family shop: $25 \%$ of their mothers did so, in contrast to $15 \%$ of the employed wives' mothers.) And, if one looks at the occupational spread of the two groups of husbands, it quickly becomes apparent that it is the employed wives who may have married into a higher social status: $46 \%$ of them are married to professional men while only $31.5 \%$ of the housewives are.

In terms of actual household organization, the two groups present some differences. Most live in nuclear families, but in the case of more complex organization, it is the housewives who are more "modern" and the employed women who are more 
traditional. In other words, the women with outside jobs are the more likely to have their in-laws or own parent co-resident (see Diamond, 1973b). They expect and receive considerably more help from extended family members than do the housewives. In some cases, a mother-in-law or mother came to live with them during their children's infancy in order to make it possible for them to continue working. In other cases, the mother-in-law is there permanently and is willing to help with child care and the domestic routine to an extent that an unemployed housewife is seldom helped by a live-in mother-in-law. This raises a host of questions about the nature of that particular relationship, which we will return to presently.

Another important element in the employed wife's household is the presence of a servant, made possible by the higher income of a double-wage-earning family. In the past, $45 \%$ of the working couples could afford full-time servants, while only $20 \%$ of the housewives had them in single-income households. At the time of the interviewing, $12 \%$ of the working couples still had servants, compared with $6.5 \%$ of the housewives. What this means in effect is that between servants and helpful relatives $84 \%$ of the employed women had help at one time or another with domestic chores and child care, only $41 \%$ of housewives had similar help, though the number would be larger if they had earned a salary to pay for servants

In cases where mothers-in-law and servants could not be brought into the household, the employed wives have been better able to turn to their husbands for assistance. On the other hand, markedly fewer of their husbands allowed themselves to become involved in the mechanics of child care $(5 \%$, compared with $19 \%$ of housewives' husbands), suggesting strongly that even though a certain equalitarianism operates between working husbands and wives, the line is drawn at parenting. This is defined as a woman's task, which explains why roughly $20 \%$ of the employed wives interrupted their careers during the early child-rearing years and why salaries for servants or the cost of nursery schools is paid out of the wife's earnings. 
Among those who were housewives, marriage and termination of work came simultaneously for $20 \%$, in some cases because they were employed in situations where resignation was mandatory. Another $32 \%$ worked until their first pregnancy and then dropped out of the labor force. Almost 17\% stopped because there was no perceived economic need for them to work. Six percent stopped specifically because their husbands disapproved. Oddly enough, $14 \%$ of the employed women also said that their husbands disapproved completely, and another $14 \%$ said their husbands had reservations, but they had not, for the most part, allowed this to interrupt their careers.

For housewives, the domestic role has been allowed to take full priority, yet there is ambivalence about it. A third of them indicated that they would prefer to be working but that they had no choice in the matter, and $40 \%$ expressed hope that they could find jobs after the childen had all finished school. But half of them were convinced that house and children come before all else in a woman's life-the others expressed concern about using their knowledge, about self-expression, and about finding enjoyment in life. Ambivalence and discomfort with their role are also found among the employed wives. Only $10 \%$ expressly felt they would rather stay home, but $44 \%$ did not think it right for a woman to work when she had young children (even if they had done so). Another 26\% thought that a woman's first duty was to look after the household, even if they were not doing so. But these women continue to work. despite the contradictory feelings and guilt, $80 \%$ had unbroken careers except for involuntary unemployment due to the war or health problems. And only $12 \%$ mentioned money as a primary reason for working-they were far more concerned about the enjoyment they found in their work, the chance to use their knowledge and the psychological gratifications. Ten percent had reached a happy compromise by deciding that they were working in order to give the children added advantages in life and thus fulfilling their maternal role.

The main dissatisfaction with the role of housewife in modern Taiwan, and particularly in the growing new middle 
class, is that it usually involves considerable social isolation, far beyond that depicted for American suburbia or city. The middle class we are discussing is spatially mobile as well as upwardly mobile. They flow into the cities from the rural hinterland, leaving kinfolk behind or scattered to yet other locations. The husband's entry to the city may be smoothed by school and army connections through which he locates a job and gains access to a network of friends. The woman, unless she is working and able to establish friendship networks on the job, must rely on whatever kin and former schoolmates she can locate in the city-and sometimes there are none. Moreover, as we have seen, she is less and less likely to have resident kin or servants, and thus during the children's early years is hampered in traveling to see friends or kin who live at any distance. (I might add parenthetically that the private home telephone is still a tremendous luxury in Taiwan and not a common item even among the middle class. One has a color TV, refrigerator, hi-fi set, motorcycle, and even a secondhand car long before one has a telephone.)

In a smaller city, such as Tainan, the question of distance from kin is not as severe as it is in Taipei. Only $25 \%$ of the total sample had no relatives in the general Tainan area, and half the sample did manage to see close relatives such as parents and siblings at least once a week (this, of course, includes the 50-odd households living patrilocally and the 14 which incorporated the wife's mother). But ties to kin beyond the immediate household are weak, particularly to those living in other parts of Taiwan who are seen once or twice a year at best-in some cases never (or so 47 of the households reported).

Reliance on the immediate neighborhood also breaks down among this middle-class group. Partially this is due to the physical arrangement of middle-class living high walls around houses or apartment entryways, topped with barbed wire and jagged glass, so that each unit is totally blocked off from the adjacent ones. Apartment complexes and entire neighborhoods are built without provision for play space and gathering space. Spatial isolation is the norm, unlike the peasant villages where 
houses are open and there is social space shared by people from different households. Another factor operating against neighborliness is the heterogeneous quality of the street, which may have squatter shacks on one end, working-class housing at the other and expensive middle-class townhouses scattered in between-it is difficult to cross class lines to make friends. Yet even where there is homogeneity, neighbors may maintain social distance.

One of our informants, for example, lived on a street reserved for persons employed at high levels in one of the local government organizations. Although the husbands were all acquainted with each other through work ties, many of the wives remained strangers. Our informant had lived on the street for fourteen years but had made no close friends among her husband's colleagues' wives. Nothing was organized to bring them closer together and no attempts were made to integrate newcomers. The best possibility for initiating a relationship was that a new arrival might be a former schoolmate or work associate, or carry a letter of introduction from someone close to an established resident. Otherwise, it would take several years before the women would be on chatting terms, a degree of relationship arrived at after several New Year's calls or brief conversations at the yearly banquet held by the organization for its staff.

Some of the women compensate for the absence of neighbors by involving themselves in religious activity. For the most part, the women in this social class are not likely to be active in local temple organizations-only 15 women in the entire sample paid monthly visits to local Buddhist and Taoist temples, and only 6 saw themselves as frequent temple-goers. Moreover, that does not imply participation in a group. Almost $37 \%$ of our sample, however, had found their way to the Catholic or Protestant church, which is a high figure considering that Christians are at most $5 \%$ of the total population of Taiwan. In some instances, it was a family matter with the husband also belonging to the church, but in 27 households only the wife was Christian and the husband did not participate at all. Usually, attendance was 
on a weekly basis. For a few, religion had swelled to great importance in their lives-for some $10 \%$ in the entire sample, church involvement meant attendance several times a week or even daily. Several of them had joined storefront fundamentalist sects that had daily prayer meetings, though this was three times more likely to occur among full-time housewives than among either employed wives or those working part-time. Friendships in this group were usually church connected.

For those who reject the religious community (and 53 of our women were professed atheists), what are the alternatives for finding friends and maintaining friendships? For a small number, the answer is that there are no alternatives: $11 \%$ of the housewives and $8 \%$ of the working wives stated that they had no one they could consider a friend in the Tainan area. The neighborhood, as already mentioned, provided few friendships. Of the housewives, who spent their entire day at home, only $3.7 \%$ could claim good friends within the neighborhood. This figure is not much better than the employed wives (27\%) who were away from the neighborhood at least eight hours a day. Loneliness is somewhat relieved by visits back and forth with neighboring women even if one cannot regard them as good friends, and $22.2 \%$ of the housewives had reached that level of relationship within the neighborhood $(9.8 \%$ of the working wives had managed similarly). The remainder were limited to brief greetings or an occasional walk together to the market and back, and a few did not even have that, ignoring their neighbors completely.

Another workable alternative is to locate former classmates and workmates in the city and retain those friendships and build on them. Well over half of the wives have kin ties in the Tainan area, suggesting that many spent their earlier years there as well. As a result, some $37 \%$ had been able to retain ties with former classmates, this in some cases overlapping with colleagues at work. In addition, about 30\% initiated new friendships at work as their main source of friends.

In the Western world, many women's friendships after marriage are originated through their husbands. That is, they are 
able to draw on the wives of their husbands' friends and associates. In the Taiwan middle class, this seemed to be possible for only $5 \%$ of the sample. For $70 \%$ of all the women, husbands' friends' wives were virtually strangers, not even visited occasionally. In a large number of cases, they had not even met their husbands' friends, let alone the latters' wives. This is because male recreation activities tend to take place outside the home: men meet their friends at restaurants, coffeehouses, and less respectable establishments. If friends come to call, they usually are not accompanied by their wives, and the woman of the house is not expected to entertain them beyond serving something to eat or drink. The more sophisticated mainland-refugee families are more likely to visit as couples and entertain as couples, or so we deduce from the fact that only $4 \%$ of the mainland wives claimed never to have met any of their husbands' male friends, while $22.5 \%$ of the Taiwanese wives made that statement.

Perhaps ethnicity plays a part here. Tainan is a very Taiwanese city, with relatively few good restaurants offering good mainland Chinese food (the two best restaurants in town are, in fact, Japanese!). This in itself may explain the greater frequency with which mainlanders spoke of inviting friends to the house for dinner. Ethnic loyalties certainly play a crucial role in selection of friends: 41 households defined all their friends as tongxiang, 98 said most friends came from the same region or province, and 34 said half. The rest were flexible, sometimes by default, as in the case of a woman from Yunnan.

Be that as it may, most of the women claimed they had few friends, and these were mainly women known before marriage. Sociability in Taiwan is somewhat difficult for both sexes, however. Grichting's (1971) survey work gives women only a slight edge over men in terms of depth or frequency of social contacts with neighbors, and as one might expect, the greater the size and complexity of the community, the less interaction there is. Interaction with neighbors decreases with rises in level of education. He also finds a peculiar reticence in discussing various issues both with those defined as good friends and with 
one's spouse, a hesitancy which oddly enough increases along with education (Grichting, 1971, 279, 289, 290, 232).

This element of caution warrants some further discussion and elaboration. E.-K. Yeh, the psychiatrist, comments in a recent article on "the prevailing defensive and distrustful behavior among Taiwanese" (which includes mainlanders living in Taiwan). He attributes this phenomenon to the strict political control and the general political atmosphere which inclines people to caution in personal interaction to avoid being "cheated" or betrayed. As he puts it (Yeh, 1972: 337-338):

Stated in the extreme, one may need to be more or less paranoid about others and one's surroundings in present day Taiwan: this was illustrated in the results of a questionnaire study of a large group of students in a major urban university in Taiwan. More than half of the students, $54.8 \%$, responded positively to the question "Do you feel that the outside world is full of traps so that you must be very cautious to be free from plots that someone may have against you?" 21 percent agreed with the statement "Someone was deliberately making trouble for you so you hate them very much"; and nearly one-fifth of the students felt that people were often criticizing them. Unless patterns of paranoid behavior are sharply deviant, they are not regarded as unusual, and may even be considered common, in present-day Chinese society.

Some of the "paranoid reaction," Yeh goes on to say, is explicable in terms of cultural factors (insecurity outside of the family network, the emphasis on keeping harmonious relations, fear of shaming, and concern with face), but he also relates it to the strict security controls of the present regime.

And indeed one does need to look to political explanations as well as cultural ones to understand why, in Grichting's survey, only $44 \%$ of college-educated people would be willing to discuss local elections with a "good friend," and worse still, only 55\% felt they could discuss it with their spouses (Grichting, 1971)! The caution extends from politics to important matters concerning the individual: in that same group, $40 \%$ would not tell their best friends that they were having trouble on the job, and $30 \%$ would not tell their spouses. In fact, the college 
educated were more likely than any others not to tell anyone about the things affecting them. Human relationships are edged with caution, and the caution infects even the marital relationship and the immediate family unit. It perpetuates a distance between spouses which reaches its highest levels in that educated (that is, middle-class) segment where marriages are usually assumed to have been contracted on the basis of choice, affection, and mutual interest.

Apparently one brings home to the family the lessons learned in the outside world. Those who have reached the highest levels in the educational system are also those most aware of the pressures and dangers of the outside world. From the first entry into school the message is brought home that one person's success is another's failure, that one is always being ranked and measured and perhaps rejected. Those who survive the strains and have some talent emerge into the search for a good job, a quest which requires the good will and support of others as much as the items on one's vita These are problems not faced by farmers, factory workers, small merchants, and the like. They are middle-class problems which continue to influence one's relations to others.

Moreover, they occur in a setting which is truly dangerous for the naive and unwary, or for those who have made enemies for themselves. The government encourages an atmosphere of distrust and betrayal in its sporadic attempts to uncover political deviants. In the early 1960s and again in 1970, for example, the government launched campaigns urging people to report any evidences of procommunist or Taiwan-independence thinking and activity among their kin, friends, colleagues, or acquaintances. Amnesty was promised to those who made a clean breast of things and brought in other names against whom charges could be substantiated. Financial reward was also promised, both in lump sum and as a percentage of the property of those successfully prosecuted. Some people must have responded, some threatened to and others simply took it as a further lesson that silence and evasiveness are the best policy. If the government really expects people to turn in their family 
members and friends, then who can be trusted? In addition, these campaigns threatened punishment for those who did not report any substantial suspicions about close family members or friends. For example, if your best friend is arrested, you will at least be interrogated by the military police about why you did not report your friend five years ago. The lesson to be drawn from that is that it's best not to know too much of other people's social views.

Let us return to our middle-class sample and look at the husband-wife relationship itself. Though we have suggested earlier that some of these marriages come close to equalitarian working partnerships with a shared social life, the majority do not fall under that description. One obvious reason is that $44 \%$ began as arranged marriages with little or no meeting of the couple ( $25 \%$ had never met until the wedding day; the rest were allowed a few interview meetings and asked for their opinion). Despite all the talk about love's being the basis for marriage in a modern society, dating is officially frowned on for high-school students, and even college girls would think twice about accepting an invitation to a movie, a coffeehouse, or a dance party. The various popular books on marriage and family still suggest that it is best to let parents make the initial choice and arrangements, and that love starts with the honeymoon.

Social patterns in Taiwan being what they are, women are not usually included in their husbands' social lives, nor do they expect their husbands to relinquish their outside socializing in order to spend more time with the household members. Roughly a third of the women said that at most they went somewhere with their husbands two or three times a yearusually to visit relatives or attend a company banquet. Thirteen percent insisted that never did their husbands take them anywhere publicly. At the other end of the spectrum were the $28 \%$ who accompanied their husbands somewhere at least once a week. This is a new pattern, since there is no stigma attached to a man's spending his weekends and evenings with friends rather than family. In fact, he lays himself open to teasing and ridicule from his peers if his wife frequently accompanies him or if he expresses a preference for staying home at night. 
The employed wives are in a somewhat better position-at least $40 \%$ of them claimed that their husbands sometimes took them along when they went to visit friends, a claim that was made by only $30 \%$ of the housewives. Employed wives also stood a better chance of being taken out for an evening to the movies (with or without children)-almost $70 \%$ of the working wives reported this, compared with $56 \%$ of the housewives. And if our coding of positive and negative affect in the husband-wife relationship is at all meaningful, employed wives had a slight edge in feeling that their relationships with their husbands were satisfying and happy.

Even though I could not do a long series of increasingly intimate interviews with the 240 women in my study, I would say that relatively few were markedly unhappy in their marriages. But only $40 \%$ in both groups felt that they had companionship, affection, and emotional support from their husbands. Another $40 \%$ had not really expected these things and were less disappointed or were resigned to their absence: their reason for getting married was that they had no alternative, that a woman must get married. Having marital status, a home, and children may be sufficient for some. For the remaining $20 \%$, it was not enough.

Children, of course, bring tremendous emotional consolation as well as fill one's time with the feeling of doing something worthwhile. Housewives in particular feel that until the children are in college they require a great deal of time and attention. In the Taiwan situation they need perhaps even more attention and time than in the American middle class. Middle-class children in Taiwan are not expected or encouraged to play on the street with other neighborhood youngsters during their preschool years. This is regarded as a lower-class pattern in the cities. Middle-class children play in the yard or in the house, attended by their mothers and perhaps some carefully invited young friends. Once they start school, the mother's days are freer, but her afternoons and evenings are busier as she becomes involved in the task of tutoring the children and helping them with their homework. Education is highly valued in the middle 
class, both as a stepping-stone to a career for boys and as a key to a good marriage for girls. The intense competition in the school system and the problems of getting into good senior high schools and colleges are a source of concern to children and parents alike. In the later school years, middle-class children have tutors or attend cram schools if their work is not of top quality. In primary school and early junior high, tutoring is the mother's task. Fathers participate much less often, despite their higher levels of education-most likely because their own social schedule precludes their being home regularly every evening. The average tutoring time was estimated at one hour a day per child, running higher, of course, around examination time.

These tasks place more of a burden on the housewives because of demographic factors. Limitations on family size were more assiduously or successfully pursued by the working wives, half of whom had one or two children, three-quarters of whom had three or fewer children. In contrast, $44 \%$ of the housewives had four or more children and another $28 \%$ had at least three. If properly spaced out, the responsibilities of motherhood can thus stretch over some 25 or 30 years until the youngest child enters college. And that is the span of time that most housewives have in mind when they say, "Perhaps I will look for a job when my youngest child is grown up." They really mean that they are out of the job market permanently.

Their days are spent absorbed with the children, with household tasks, with make-work and solitary recreations. Only eleven women in the entire sample said that in their free time during the day they would ordinarily visit a friend. Almost all had television sets, and almost half watched from three to five hours a day (most of the watchers were, of course, housewives) in their free time. Others spent their "free time" doing handicrafts, finding additional household chores to do, playing with the children, or reading novels and magazines.

As was said earlier in this section, there is a certain amount of diffuse dissatisfaction and ambivalence about roles among the women in this group. The housewives, many of whom came from large families or smaller communities, now have to cope 
with isolation, loneliness, and a feeling that many of the tasks they perform are boring and held in disregard-even servants will not do them any longer.

Those who are working have found a solution to the problems of loneliness and uselessness which most of them consciously identify with the housewife role. But at the same time, they are guilt ridden and anxious that they are failing to fulfill their required roles as mothers and homemakers, even when they are able to recruit other women as surrogates for those tasks.

\section{A FEMINIST STATEMENT}

We have pointed to some evidences that women are not totally convinced that the nuclear family/housewife model is the most satisfying or worthwhile. Another kind of indicator is the success of a relatively new magazine, The Women (Funü zachi), which in a quiet way has addressed itself to feminist issues. During the early 1970s it ran articles on such subjects as the need for day-care centers, women's legal rights, the women's movement in other countries, abortion and birth control, and presented models of career women and suggestions of career lines for women beyond the stereotypically acceptable ones. In 1972, a feminist group was formed at National Taiwan University among students and younger faculty women, and I am told that similar groups are quietly operating elsewhere. In 1974 a book on the "new feminism," taking an understandably moderate stance, was published by one of the leaders of the National Taiwan University group (Lu, 1974). Though to those of us who have been in the women's movement in the United States the author's criticisms of social and economic discrimination seem restrained, she has apparently been under attack and her position interpreted to mean that she favors "open sex" and the abolition of the family. Neither of these extreme positions is anywhere evident in the book. Most significant is that small number of women who manage to maintain a 
working life outside the home without being forced to it by economic need and who support the idea of an equalitarian marriage, despite the heavy weighting of the mass media against these ideas. That they exist, that they continue to exist and set an alternative model for others, is an indicator of the felt shallowness of the role that is officially and popularly assigned to women. However, most of the women in the Taiwan work force are there out of necessity, and many are only temporarily in the work force.

Despite the official proclamations that men and women enjoy equality in Taiwan, many women suspect that this is not the case, or are sure it is not. The disappearance of the joint and extended family unit as a desired model fails to solve the basic problem, which is that of women's relationship to the rest of humanity (men). The rejection of the complex family unit does nothing to change the relationship between men and women in the economic and political world, and very little to change their relationship in the domestic sphere. The question of male chauvinism is clouded over and hidden by the supposition that the oppression of women within the traditional Chinese family stemmed mainly from other women. This is not to deny the real tensions and antagonisms that often existed between mothersin-law and daughters-in-law, or between sisters-in-law, but it is possible that these have been exaggerated or overemphasized by Western as well as Chinese scholars. The older women in the household might in many cases identify with the young newcomer and welcome her companionship (in some cases the only adult female companionship available once their own daughters married). In the case of cross-cousin marriages with mother's brother's daughter, the older woman would be welcoming her own kinswoman into the household. The crucial role played by women in the selection of a daughter-in-law also mitigates against the possibilities of antagonism and rivalry, since it puts on them the responsibility for the choice. Older women and daughters-in-law may also share an interest in the care of the next generation, which brings the daughter-in-law into a relationship of dependency rather than rivalry. 
The family situation described in "Gold Flower's Story," for example (Belden, 1970. 275-307), makes clear that the abuse and terror inflicted on the young woman in her marital home stem from her husband and father-in-law and not from the mother-in-law, who is described as a sick and passive woman. She is beaten, starved, and denied the creature comforts, and when the village is liberated, it is her father-in-law who is hauled up for criticism and threats of retaliation. At the same time, we must keep in mind that there were women so brutalized by the treatment they received, at whoever's hands, that they lived for the day when they could retaliate and inflict similar suffering on others. Inflicting it on men was impossible; but they could turn on their adopted daughters, their daughers-in-law, or perhaps even their own children. The mother who bound her daughter's feet repeated what had been done to her as a child, despite the suffering that she knew was involved. The older woman who abused her daughter-in-law or adopted daughter repeated an acceptable pattern set in the past. But it was not some natural viciousness of women-against-women operating here. It was women as agents of male authority, helping to create another generation of submissive and obedient wives and mothers. The shift to the nuclear household does not axiomatically change the position of women in the household. It only shifts more of the burden of control over women to the husband and to the society at large. To many housewives it becomes clear that the absence of a mother-in-law does not provide freedom from household tasks, nor does it enable them to widen their social circle or operate in the world outside the home. At best, it spares them a non-compatible co-resident and simplifies some household chores while increasing others. It does not raise their social position. In the willingness and even eagerness of some of the employed wives in my sample to have co-resident mothers-in-law one sees this realization more clearly: the mother-in-law is not a threat to a freer life-style. On the contrary, she can be an active supporter of it, as demonstrated by her willingness to take on the domestic burden.

The urban nuclear family inflicts a different kind of oppression on its women from the overt physical oppression so 
often cited for the past. It is psychological oppression that is bound up with social isolation and the contradiction between receiving an education and the absence of alternative ways to put that education to use. That education is available to women is again one of the items cited to "prove" the equality of women in Taiwanese society. Those women who have managed to gain a senior middle-school education are, objectively speaking, of higher scholastic aptitude than the population of male senior students if only because they faced stiffer competition in order to gain that level of training. With only one-third of senior middle-school places available to women students, and with fairly rigorous competition for admission for all (one-tenth of primary-school students in the 1950 s survived to graduate from senior middle school, and one-fifth in the 1960s), those women who reach even that level of education would be justified in regarding themselves as part of the intelligentsia.

For college-educated women, the feeling of specialness is even more justifiable. Women are again limited to a third of all college entrants (though as a result of the examination system they have in recent years managed to constitute almost $50 \%$ of those accepted at National Taiwan University) and this in a competitive system in which until recently only one in a hundred youngsters survived to enter college or higher-level technical schools. Yet academic excellence and progress through the school system are no guarantee of anything. Official government statistics suggest that a high percentage of collegeeducated women (close to two-thirds) are working. However, an attitude survey done by the sociology department at National Taiwan University (in which $31 \%$ of all the women were college educated) suggested that only $44 \%$ of college women were employed whereas all the college-educated men in the sample were working (Chang, 1968). Social unrest would probably ensue if only $44 \%$ of the college-educated males held employment. But in Taiwan, as elsewhere, many women accept the traditionally assigned roles-well over half the college women in that sample agreed that "men's work is outside the home, women's work is inside." So did $83 \%$ of the college-educated 
men in this particular survey. At the same time, only $9.7 \%$ of the women in the total sample thought that women did not have the same abilities as men, and $76.8 \%$ thought that a woman could go out to work even if there were no pressing economic reason for her to do so. It was college men in the sample who were the most likely to think women did not have the same abilities as men, and to be most adamant about hiring men in preference to women. The male resistance to female employment is strong, whether they be men in their role as husbands, in their role as employers, or in their role as colleagues.

Interestingly enough, it is in the most modernized area of Taiwan that the resistance to women working is the strongest. Proportionately, more educated women find jobs outside of Taipei.

In Taipei, the lodestar metropolis where over a third of Taiwan's male college graduates have settled and found employment, there are problems for women seeking work. The women graduates of teachers colleges and teacher-training institutes are less employable than men. only 2,632, many of these yet unmarried, work full- or part-time, while 3,726 are housewives. Their male counterparts are all employed, some in nonteaching middle-class jobs. However, outside of Taipei the situation is considerably better for women. There we find that of the women graduates trained as teachers, some 17,000 are working and only 4,000 are full-time housewives. And some have found jobs other than teaching. As for women trained in regular universities and colleges, they too do better in the hinterland. In Taipei, 14,643 are employed, 1,023 are listed as unemployed, and 4,239 are housewives. Outside of Taipei, 19,000 are employed and 4,000 are housewives. Moreover, in Taipei $86 \%$ of the college women employed are under 25 years of age, while outside Taipei the figure drops to $70 \%$, suggesting that more women there remain at work after marriage. On the Taipei scene, women graduates of senior vocational and technical schools do find work, but half of those employed are under 20. Outside of Taipei only $30 \%$ of these employed graduates are 
under 20. As for graduates of senior middle schools, in Taipei they are clearly disadvantaged. Only 6,374 are employed, compared with 20,636 who are housewives and another 3,000 who describe themselves as unemployed or unable to work or disinterested. But outside of Taipei, while 26,000 are housewives, there are 21,000 who are employed (see the October 1970 Quarterly Report on the Labor Force Survey).

How do we explain these statistics? One possibility is that with the flight of male talent to the metropolis, women elsewhere have an easier time finding employment. Another possibility is that with the lesser concentration of mainlanders outside of Taipei the adherence to the KMT thinking about women is weaker. One way they cannot be explained is in terms of lower salaries outside of Taipei encouraging men to allow their wives to work. The high cost of living in the metropolis more than wipes out any advantages of higher pay: it is males in Taipei, if anywhere, who should be more eager to have their wives working to bring in additional income.

To return from this slightly tedious digression into figures, let us again address the question of access to education as an indicator of equality for women. It should be clear that education in itself does little, or at least it is not, in and of itself, a solution. Many of those who have received educations suiting them for middle-class types of jobs are in fact not using their educations to that end. This reflects the ideological continuity in the Kuomintang since the inception of the New Life Movement as regards the purpose of education for women. Briefly stated, that viewpoint holds that educated women make better wives and mothers, better householders and citizens. The major purpose in educating women is to enable them to teach and rear their children more effectively. As mothers, they can provide not only the moral training but also the educational input which will ensure success for the children as they move through the school system. As such, education expands the domestic role rather than being a tool by which women are enabled to take a place in the wider society. This is an obvious break with the spirit of the May Fourth Movement and the earlier days of the KMT revolution. 
Education also becomes an end in itself as a symbol of elite status. It is one factor in defining the social position of a household. Women can draw considerable consolation from this as well as from the idea that the housewife/mother role is upgraded through its educational input. But operating concomitantly with these positive ideas is the feeling that even with education women are less able and less talented than men. This feeling has manifested itself in recent years in the public discussions over the high rates of examination success of women in gaining admission to National Taiwan University. The general thrust of the discussions is that women students are simply better equipped for blind memorization of texts and classroom material. Their high scores, in effect, are to be taken as indicators not of scholastic ability and creativity but only of their more submissive, obedient, and/or compulsive "nature." In the past couple of years, arguments against academic and job training for women have gained force. Recent proposals have seriously suggested cutting back female college admissions by two-thirds of the present level, a suggestion which if put into effect now would bring women's college enrollment to $10 \%$ of the total. Only the truly exceptional and outstanding women would ever enter college. At the same time, it has been proposed that the senior middle school and junior colleges concentrate on expanding their home-economics programs as a major course of study. Thus, women can have the symbolic prestige of a degree in a field specifically preparing them for marriage. Combined with this are suggestions for reducing the vocational and commercial senior middle-school facilities for women in order to further reduce possible competition for white-collar jobs (see Tsui et al., 1972).

Finally, we return to the assumption that male-female equality is achieved through basing marriage on love, mutual attraction, and choice, which, whatever the realities may be, is the way that modern marriages are defined in Taiwan (as in most other parts of the industrial world). Although these elements may be necessary to an equalitarian relationship between husbands and wives, they are not sufficient to ensure 
equality for women either within the domestic unit or outside of it. They are, alas, not even sufficient to ensure domestic happiness over the course of the years. As my own data and that of others have indicated, there is often emotional distance between spouses, lack of trust, and separate lives even when the ideal of the marriage-by-choice and nuclear family has been reached. A quick survey through the various publications aimed at women, be they private or government sponsored, shows that they tend to lay the major blame for domestic dissatisfactions on the woman herself, burdening her with guilt and anxiety. This again is a psychological form of oppression.

Only in a limited sense is there equality within the domestic sphere. Women do have a measure of control over household expenditures and within limits can allocate their time to different tasks as they choose. Because they are often the only adults in constant interaction with the children, they have authority to discipline them and have more of a say in the children's activities and future course. As a result of changes in the legal system, they have property rights and can deter the husband from bringing an additional sex-partner into the household because the household is defined as being as much the wife's as it is the husband's.

However, since they also operate as extensions of their husbands' interests, they are not free to form friendship alliances for themselves. And since they are not seen as full adults, they do not have to be incorporated into the husbands' networks of friendships and social activities anymore than the children have to be incorporated. Looked at in this light, women are the foremost of the children and men are the foremost of the total household.

The real social isolation of many of the middle-class housewives gives the lie to the promise that love-marriages and small-family living provide all the emotional gratification that an adult woman would need. Some survive emotionally by devoting all their energies and interests to the children and by having a fairly large number of children in order to increase the mother-role. Some become religious activists. Others take refuge 
in magazines, pulp novels, and more recently, television, and exist in a fantasy world of love stories and trying situations which come out all right in the end. Some go insane according to Chu Hung-ming (1972), the highest rates of schizophrenia in Taiwan occur among female mainland Chinese, while Taiwanese women who have migrated to the urban centers are way ahead in the prevalence of psychoneuroses and manic-depressive behavior, with a steady and large rise between the ages of 30 and 60 (from 19 per thousand to 93 per thousand). In terms of all mental disorders, women clearly hold the lead whether they be Taiwanese in their hometowns, migrant Taiwanese, or mainlanders.

The solution to the problem is not that husbands spend more time at home (as prescribed by the "togetherness" philosophy so popular in the United States in the 1950s) but that women spend less time within the confines of the domestic world, as defined in the narrow sense. All the ethnographic evidence strongly suggests that it is only very recently that women in Taiwan society have borne so much of the responsibility alone for child care and domestic tasks. In the peasant sector, women participated to some extent in farm work, fishing, handicrafts, and marketing activities. They were able to do so because of help from children and older household members with domestic tasks and child care and because of child-care exchanges with neighbors. The wealthier classes had servants and kinswomen who also provided company of an adult sort.

Certainly women today could feel less isolated if the social patterns of the city were somewhat different-if neighborhoods were homogeneous enough in terms of social class to encourage neighborly interactions, if there were parks where mothers congregated with their children, if there were social and religious organizations for women or some form of community organization, and if married women could easily build new social networks for themselves through their husband's friends. But even that does not solve all the problems, and in the absence of these, outside employment remains the most effective way for reducing their social isolation and bolstering their self-esteem. 
Yet, increasingly, the option of suitable outside employment is less available for middle-class women. The occupations still open to women conflict with middle-class status: obviously, those women educated at the middle-school level and beyond have no interest in them. Social class (and age) excludes them. Alogether, women are about $36 \%$ of the total labor force in Taiwan. This figure includes women in agriculture, fisheries, and family shops. In $1971,38 \%$ of all factory workers were women, and half of them were under 19 years of age. Forty-six percent of what are classified as "service, sports, and recreation workers" are women-that category includes prostitutes, bargirls, dance-hall girls, wine-house hostesses, hot-springs attendants, massage-parlor and beauty-parlor personnel, hotel workers, and so on. There are also possibilities that carry somewhat more social respectability, such as salespersons, of which women make up $34 \%$ of the total, but here the preference is still for young unmarried women. The same is true of clerical workers, where women make up $32 \%$ of the total. The jobs for which women are most eagerly recruited are based on low levels of skill and education and/or short-term employment prior to marriage Only 5\% of all women have obtained jobs that are classified as professional, technical administrative, or managerial, and there they constitute at most $23.5 \%$ of these workers despite their large numbers in teaching and nursing. In brief, employment may not be a viable alternative for women who wish to do something beyond the housewife role.

In an earlier paper (Diamond, 1973a) I raised the point originally discussed by Boserup (1970) that greater involvement of women in the work force has its positive aspects, rather than the often-assumed negative one of creating unemployment for men. One of the advantages of employing women throughout the labor force is that it puts a brake on rural-urban migration, keeping some educated persons in the rural areas and smaller cities and towns to spearhead progress. In addition, it relieves the pressure on public investment in the growing cities to provide housing, electricity, water, sanitation, schools, hospitals, and the like. Two-income households pay more in taxes 
and also have more money for consumer spending and savings. Households with employed wives also tend to have lower birth rates. The net effect is that urbanization proceeds at a slower pace with less of a gap between metropolis and hinterland, and with less strain and dislocation. I think there is no doubt that the adjustment of male household heads to modern urban living has been relatively smooth (aside from certain tensions over the high cost of living and the difficulties of stretching a single salary to meet all family needs). Little has been said about the effects of modern urban living on the wives of these men, and since society encompasses all members, it would be fair to say that the new life-styles are difficult and sometimes quite painful for half of the adult population.

The government in Taiwan, however, is not interested in filling the work force with working couples. Governmental planning tends to equate "development" with rapid urban growth and concentration. It also tends to equate "development" with the growing numbers of foreign-owned factories and corporations, even when the profits from these leave the country while the goods they produce are locally available only if channeled back through foreign markets at greatly increased price. The main attraction for these enterprises is the availability of a work force whose individual salaries rarely exceed $\$ 30$ a month for a 48 -hour week with no threat of strikes or labor-union pressure. Much of this labor is supplied by women. Urging young women into the lower ranks of the work force helps meet the goal of rapid industrialization-never mind whose industry it is. Reserving the jobs in the middle and upper ranks of the work force for men helps meet the goal of rapid urbanization: for each man hired in the metropolis the population is increased by one woman and several children. Taipei continues to grow at an alarming rate, with all the practical problems of a "boom town," including inadequate facilities for children.

One social service that is conspicuously missing is adequate child-care service for those women who can locate jobs and may wish to work. Servants are difficult to find because of the large 
numbers of young women drawn into industry, sales work, and entertainment Kindergarten facilities, public and private combined, can accommodate only one in ten potential applicants, and there are even fewer facilities for children under the age of four. Moreover, children attending kindergarten and the early grades of elementary school are often on half-day shifts which do not coincide with business working hours. After-school play centers are rare, except in private schools. Despite government assertions that no occupation is denied to women, the realities of the situation are such that it is increasingly difficult for married women with children to take employment. That so many devise ways to do so, in face of the difficulties, and often in the absence of any pressing economic reasons for doing so, is a testament to their strength, determination, and need.

It is obvious that in comparison with their sisters on the mainland of China, the women of Taiwan are in a disadvantaged position. In Taiwan only the content of women's oppression has changed since traditional times, enabling some to create life-styles that give them autonomy, dignity, and a more equal status both in the home and in society at large. But for many life contains a new form of oppression. Though educated and qualified to participate in economic, social, and political life, they are discouraged from doing so by both formal and informal means of control.

The decline of feminist aspirations, their absence from the published and proclaimed programs and goals of governmentapproved women's organizations, is not the fault of the women. The retreat into domesticity stems only in part from the backlog of traditional beliefs about women which defined them as less able, less talented, and less strong than men and which defined their role as "inside the house." The terms neiren and neizi are still used in Taiwan in reference to wives. The official line on women sees them in domestic and supportive roles once they are married. Little is done to make other alternatives viable, and even more, those who take on a different life-style are subject to criticism and vulnerable to feelings of guilt. If they have children, they are made to feel 
anxious and ashamed by charges of selfishness and unmaternal feelings. That too is a form of oppression.

One final comment the position of women in Taiwan (or any other developing country) cannot be understood simply by looking at the traditional base and asking what markable changes and continuities there are in the present or what has been borrowed from the West. It is necessary to bring into the picture the political and economic changes that have occurred in recent years and to see how they are related to the directions that the changes and continuities have taken.

\section{REFERENCES}

BELDEN, J. (1970) China Shakes the World New York: Monthly Review.

BOSERUP, E. (1970) Women's Role in Economic Development London: George Allen \& Unwin.

CHANG, XIAO-CHUN (1968) A Study of the Attitude in China Towards Employed Women. Taipei: National Taiwan University Department of Sociology (in Chinese with English abstract)

CHIANG, KAI-SHEK (1935) "The New Life Movement," pp. 33-42 in T'ang Leang Li, Reconstruction in China Shanghai: China United

China Yearbook, 1969-1970 (1971) Taipei: China Publishing

CHU, HUNG-MING (1972) "Migration and mental disorders in Taiwan," pp 295-325 in W. Lebra (ed.) Transcultural Research in Mental Health Honolulu: Univ of Hawaii Press.

DIAMOND, N. (1973a) "The middle class family model in Taiwan." Asian Survey 13 (September): 853-872.

- - (1973a) "The status of women in Taiwan," pp 211-242 in M. Young (ed ) Women in China. Ann Arbor: University of Michigan Center for Chinese Studies.

EASTMAN, L. (1972) "Fascism in Kuomintang China" China Q. 49 (January/ March): $1-31$.

Free China Review (1971) "Where women's lib has been achieved." (March): 35-42 GRICHTING, W. (1971) The Value System in Taiwan, 1970 Taipei.

HAHN, E. (1941) The Soong Sisters. New York: Doubleday, Doran

HAN, SUYIN (1968) Birdless Summer New York: Bantam

HSIEH, PING-YING (1940) Girl Rebel. New York: John Day

LI XUE-LI (1970) Lianai, jiehun, jiating (Love, marriage, family). Taipei: Taiwan Commercial Press.

LU XIU-LIEN (1974) Xin nüxing zhuyi (New feminism) Taipei: Youshi Monthly Publishing

MILLETT, K. (1970) Sexual Politics. New York: Doubleday

Ronin (1972) "Suppressing the rebellion." 1 (December): 4-12 
SMEDLEY, A. (1933) Chinese Destinies. New York: Vanguard.

SNOW, H (1967) Women in Modern China. The Hague: Mouton

SOONG, MEI-LING (1938) Madame Chiang's Messages in Peace and War Hankow:

China Information Committee.

Taiwan funü (1968) 141 (March) Taipei: Taiwan funü yuekanshe.

TSUI, T K., K. LOH and M. Y. CHANG (1972) "Women workers in Taiwan-SinoAmerican conference on manpower in Taiwan." Taipei: Council for International Economic Cooperation and Development. (mimeo)

WEI, YU-XIU CHENG (1943) My Revolutionary Years. New York: Charles Scribner. YANG, JI-SUN (1964) Zhongguo funü huodong ji (China's feminist movements). Taipei: Zhengzhong.

YEH, ENG-KUNG (1972) "Paranoid manifestations among Chinese students studying abroad: some preliminary findings," pp $326-340$ in W. Lebra (ed.) Transcultural Research in Mental Health. Honolulu: Univ of Hawaii Press 